Pobrane z czasopisma New Horizons in English Studies http://newhorizons.umcs.pl Data: 26/04/2023 15:46:14

New Horizons in English Studies 6/2021

\title{
REVIEW
}

@

\author{
Barbara Klonowska \\ The John Paul II Catholic University of Lublin, Poland \\ BARBARA.KLONOWSKA@KUL.PL \\ HTTPS://ORCID.ORG/OOOO-O001-8327-854X
}

\section{(Im)possible Escape? \\ H. G. Wells, Utopia and the World State}

\section{Maxim Shadurski, The Nationality of Utopia. H. G. Wells, England, and the World State. New York: Routledge, 2020, pp. 278.}

The discussions of supra-national utopia on the one hand, and national interests on the other are a salient feature of both contemporary academic theory and popular public debates. Especially after the 2008 financial and economic crises, this double pull seems to intensify, with the dreams of a universal better state or social organization occupying one part of political spectrum, confronted with the strengthening of nationalistic sentiments and views expressed by the other. The presidency of Donald Trump in America, the successful Brexit in the European Union, and the rise and rule of quasi-authoritarian regimes elsewhere in the world seem to suggest that at the moment, it is the nationalist discourse and categories that are perceived by many as adequate responses to the present crisis and to the uncertainty about the future. Against this atmosphere of increasing political and social nationalism, the propositions of a utopian World State or a pan-world federation may sound as naïve romantic day-dreaming or outright dangerous plans, rather than a sound political alternative.

Perhaps the present climate of uncertainty and anxiety, additionally fuelled by the Covid-19 pandemic which once again confronts one with the questions of effective policies both on a national and the world scale is a good occasion to revisit and rethink the connections between the discourses of nationalism and utopia. The recent monograph by Maxim Shadurski, The Nationality of Utopia. H. G. Wells, England, and the World State 
(New York: Routledge, 2020) provides an excellent opportunity to once again discuss utopian tensions generated by nationalism on the one hand, and cosmopolitanism on the other. Although the study takes its reader back, first to the beginnings and then to subsequent decades of the $20^{\text {th }}$ century returning to the ideas of the World State projected by H. G. Wells, this excursion may serve not so much as a nostalgic revisiting or escapism, but rather as a model for analysing the present and - possibly - the future. The study discusses Wellsian concepts in an impressively broad context of theories of both nationalism and utopia, and confronts them with a wide selection of other literary texts of both Wells's times and his descendants. The monograph, divided into five chapters, recovers the trajectory of Wellsian concept of utopia on a planetary state through its various traces and manifestations. It systematically analyses how the utopian discourse presented in Wells's works is first installed in and intertwined with the discourse of England. Then the analysis shows how in the novels of his contemporaries, the utopian vision of the World State undergoes a transition, being either modified or problematised, to be rejected by the writers publishing their works after WWII, only to reappear as a simulacrum at the turn of the centuries, to be salvaged partially in pockets of hope still latently present in public debates. In so doing, the work traces the metamorphoses of the World State utopia and its complex relationship to nationalism, anchoring it in a sound and broad background of British fiction and in its political and literary culture. As such, it is an interesting study and exposition, not only of certain political and social ideas of a certain long-dead English writer but an excellent point of entry into the history of English literature, utopian models and theories, and political studies that take up the issues of nationalism. It is also a somewhat paradoxical guide to and analysis of 'Englishness' which today may strike the reader as bravely refreshing.

\section{Utopia}

As Maxim Shadurski writes in the introduction to his study of the complex relationships between utopia, nationalism and the (imaginary) World State, "since its generic inception in 1516, utopia has produced visions of alterity which renegotiate, subvert, and transcend existing places" (cover blurb) - it is, then, precisely the role of the utopian discourse to propose, in a gesture of a mental experiment, the visions of places, communities and political organizations other, and possibly better, than the existing ones. Thus intellectually challenging the status quo or the proposed political programmes, utopia's function is to ceaselessly check and counter the solutions taken in reality in the name of a better future. The monograph by Maxim Shadurski analyses how the tangle of nationalism, utopia and the concept of the World State are introduced and conceptualised in the works by H. G. Wells and then subsequently competed, countered or rejected by his contemporaries (Robert Hugh Benson, Aldous Huxley) and followers (George Orwell, Anthony Burgess, J. G. Ballard and Julian Barnes). Set against the broad context of modern theories of both nationalism and utopia, the study 
demonstrates how the utopian and dystopian $20^{\text {th }}$-century novel veers from the rejection to retrieval of nationalism on the one hand, and from the endorsement to rejection of the concept of the World State on the other.

The author conceptualises utopia broadly, as a literary mechanism of production of alternatives, without lengthy discussions infused with technical jargon and arcane distinctions, for instance those between utopia, anti-utopia or dystopia - almost standard in most studies of utopia. He contextualises his discussion referring to classical formulations and theories of utopia of Ernst Bloch (hope), Tom Moylan (emancipation), or Ruth Levitas (desire) to underline the common thread consisting of its dynamic character, liberal leaning and cosmopolitan intents which supersede nations. Thus conceptualised, utopia is seen as social dreaming about a better life and a better world. In the case of Wells's fiction - the world of the whole planet.

\section{The World State}

As Shadurski's monograph persuasively argues, Wellsian concept of utopia was predicated on the idea of the World State and envisioned as a beyond-the-nation utopia on a planetary scale. Viewed as a reaction to the atrocities of WWI, fought in the name of nationalistic interests, the proposed post-WWI 'United Humanity' is presented as a viable counter-proposition to the potentially lethal nationalistic tendencies. Wells concludes his Outline of History, Being a Plain History of Life and Mankind (1920) with the famous statement that "our true nationality is mankind" but the initial impulses for the dream of a nation on a planetary scale can be found as early as in The War of the Worlds (1898). As Shadurski observes, "repeatedly, Wells petitioned for a world organized on scientific principles, where education and open discussion would have eradicated extant armies, navies, and social hierarchies; where technology would have transformed the experience of space, time, work, and travel; and where the rule of democracy would have rendered dishonest statesmen out of service. ... For Wells, the World State was to become a place where humanity would have come into its own, a prefiguration of utopia" (5).

Interestingly, as the monograph proves, this universal World State was to some extent to be modelled on and informed by specifically English ideals and solutions. Wells believed that the English may contribute a lot to this planetary community with their constitution, landscape, character, language and the Empire, which he perceived as a forerunner of the World State providing flexible infrastructure for global communication and interests. Thus, the author suggests that H. G. Wells is a complex utopian, who tries to combine totality and universality with individuality, simultaneously English and cosmopolitan, proposing dynamic concepts constantly open to reshaping and revision. As the study demonstrates, Wellsian utopia informs and is informed by the national discourse, and may be reconstructed from both his theoretical writing and seen espoused in his scientific romances. 


\section{Utopia vs. / \& England}

As The Nationality of Utopia argues, one may notice several parallels between utopia and England. As conceived by its inventor, Thomas More, utopia is an island - just as Britain. Moreover, both of them are subject to the double logic of, on the one hand, isolation which guards their safety and self-confidence, and expansion on the other, perceived as necessary to best attend to their interests. Thus identified, isolation and expansion turn out crucial for utopia - but they are also crucial for any nationalist discourse. Analysing what he terms 'the discourse of England', Maxim Shadurski discusses closely three of its essential parameters: geography / landscape, continuity and character, each of which is presented as dynamic and complex, subject to different or even contradictory conceptualisations (e.g. visible in the tension between the 'Little Britain' ideal and imperialistic ambitions). All of them are seen as crucial for the understanding of Wellsian concept of utopia and its heavy dependence on the 'English model'. What the monograph suggestively shows, however, is the process in which Wellsian utopia does not sentimentally eulogise any form of Britishness; to the contrary, the study argues that Wells actively redeploys, transcends and subverts the discourse of England, using it to produce visions of alterity - i.e., utopia.

The analyses are based on close and detailed discussions of two of Wells's novels - Men like Gods and The Dream, with numerous references made to his other works. This part of the study shows how the discourse of England can be compatible with utopia, offering ideas and concepts potentially useful on a supra-national scale. Wells emphasises the need for continuity, although his views on social change may seem self-contradictory: on the one hand, he seems to believe that there has to be a revolution, a breakdown of civilisation of sorts, to get the world to utopia - and traces of these ideas are visible, for instance, in his scientific romances. On the other hand, his later writings invest rather in continuity and gradualism: they suggest that utopia itself is a revolution and it does not have to be additionally coupled with violence. These analyses are then juxtaposed in the study with those that discuss the novels by Wells's great contemporaries - Robert Hugh Benson's Dawn of All, which shows England in transition, and Aldous Huxley's Brave New World, which depicts England already lost in the World State. Interestingly, what the author of the study underlines, is the fact that despite their very different standpoints and types of projected visions (utopia vs. dystopia), all of these works still grant utopian possibilities, however subverted or ill-conceived they might seem to be. In the later works by Orwell, Burgess and Barnes - also discussed in detail in the following parts of the monograph - these possibilities seem to be lost. Significantly, all of these works - Nineteen Eighty Four, A Clockwork Orange and England, England - may be classified as dystopias, which in itself suggests their lack of hope for utopia or Englishness. The analysis of literary works spanning over a century persuasively presents a distance covered by utopian visions, delineating the trajectory leading from England to Britain, through the Empire and - possibly - back to England again. The study suggests, then, that the English and world utopia may 
be still construed as truly utopian in the sense that it is yet to come. At the moment, Wellsian utopia, based as it is on totality and universality, seems to be rejected as little attractive in the world climate where it is the difference and individuality that matter. Thus, the English utopia - if it is to reappear and provide a model for the World State will have to come back to England, anchor itself firmly in its particular landscape and negotiate its individual character. As such, it is still the project of the future.

\section{The Great Escape}

Maxim Shadurski's monograph demonstrates, then, that even the truly cosmopolitan utopia such as the Wellsian vision of the World State is always involved with and informed by a particular national discourse, which it treats as an inspiration and a reservoir of images, ideas and models to be employed to fully realise its potential. As the study suggests, there seems to be no escape from national anchorage and national discourse in utopia, however cosmopolitan or worldly it aspires to be. Nor should it be treated as a disadvantage - paradoxically, the 'domesticity' and familiarity of some utopian models may facilitate the absorption and acceptance of their more general tenets as well.

The close analyses of novels presented in the study take the reader into the complex and fascinating history of both $20^{\text {th }}$-century English literature and the history of ideas, at the same time provoking reflection on the present and the competing contemporary visions of federation / unification on the one hand and the increasingly militant nationalism on the other. This historical and literary part of the study is impressive if only due to the sheer number of works and authors evoked and analysed, and the meticulous recreation of the political and literary climate of the pre-war period with its discussions and preoccupations. The literary context, the number of works discussed and the studies referred to make this part an important contribution to the study of literary history. These sections will be of interest both to specialists in literary studies and to the curious non-specialist reader who may have a chance to learn about forgotten disputes and now rarely read and discussed novels published at that time.

Likewise, the sections of the study which discuss in detail political theories of nationalism, both modern and past, are invaluable in their informative value and again, they are supported with an impressive number of theories and studies referred to by the author. Although the very idea of juxtaposing nationalist ideas with those of utopia may seem surprising at the first glance - utopia being rarely discussed in nationalist terms - Maxim Shadurski's study demonstrates that reading utopia through the lens of its inflection by nationalism provides an inspiring impulse to rethink both discourses as complementary rather than mutually exclusive. One would not be wrong in concluding that both in the case of Wells's ideas and in the case of contemporary debates about the global integration and national egoisms utopia and nation state do not have to be perceived as lethal enemies and may be productively treated as allies and contributors. 
Pobrane z czasopisma New Horizons in English Studies http://newhorizons.umcs.pl Data: 26/04/2023 15:46:14

Finally, for the readers and scholars for whom H. G. Wells is a thought-provoking author, The Nationality of Utopia is a treat, discussing as it does in detail numerous of his works and theories in a broad context both of his own times and those of the following decades. For Wellsians, the study will provide a new angle of reading and discussing his works; for curious readers - an introduction into more political, less adventurous aspects of his novels. In the last analysis, then, the (im)possible escape from - or plunge into - nationalism, cosmopolitanism or utopia, which in this study constitute the parameters of discussion of Wells's works, those of his followers and contemporary political debates, due to Maxim Shadurski's monograph may turn out to be not so escapist at all. 